\title{
In Vitro and In Vivo Anticancer Activity of Human $\beta$-Defensin-3 and Its Mouse Homolog
}

\author{
YOKO HANAOKA ${ }^{1 *}$, YASUHIRO YAMAGUCHI $^{*}$, HIROSHI YAMAMOTO ${ }^{1,2}$, MASAKI ISHII $^{1}$, \\ TAKAHIDE NAGASE ${ }^{3}$, HIROKI KURIHARA ${ }^{4}$, MASAHIRO AKISHITA ${ }^{1}$ and YASUYOSHI OUCHI ${ }^{1,5}$ \\ Departments of ${ }^{1}$ Geriatric Medicine, ${ }^{3}$ Respiratory Medicine, and \\ ${ }^{4}$ Physiological Chemistry and Metabolism, Graduate School of Medicine, \\ The University of Tokyo, Tokyo, Japan; \\ ${ }^{2}$ Department of Respiratory Medicine, Tokyo Metropolitan Geriatric Hospital, Tokyo, Japan; \\ ${ }^{5}$ Federation of National Public Service Personnel Mutual Aid Associations Toranomon Hospital, Tokyo, Japan
}

\begin{abstract}
Background/Aim: Defensins comprise a family of mammalian cationic antimicrobial peptides. We investigated the anticancer effects of human $\beta$-defensin-3 (hBD3) and its mouse homolog, Defb14, on lung cancer cells. Materials and Methods: We stained lung cancer cells cultured after treatment with the defensin peptide using propidium iodide and Hoechst 33342. In vivo, Defb14 peptide or vehicle was continuously infused near subcutaneous Lewis lung carcinoma cell tumor in mice. After 9-day infusion, the weights of excised tumors were determined. Results: A 10min treatment with hBD3 $(70 \mu \mathrm{g} / \mathrm{ml})$ induced propidium iodide uptake in lung cancer cells. The anticancer activity of hBD3 was significantly more potent than the activity of other defensin isoforms. Continuous infusion of Defb14 peptide showed significant tumor-growth suppression in Lewis lung carcinoma cells in mice. Conclusion: Our study demonstrated the suppression of tumor growth by Defb14 peptide in an animal model.
\end{abstract}

Antimicrobial peptides have emerged as a part of the host defense mechanism in both animals and plants $(1,2)$. Specifically, defensins and cathelicidins are antimicrobial peptides found in humans (3). In the defensin family, there are $\alpha$-defensin and $\beta$-defensin subfamilies, which conserve three specific disulfide pairings. These are produced by

\footnotetext{
*These Authors contributed equally to this study.

Correspondence to: Yasuhiro Yamaguchi, Department of Geriatric Medicine, Graduate School of Medicine, The University of Tokyo, 7-3-1 Hongo, Bunkyo-ku, Tokyo, 113-8655, Japan. Tel: +81 358008652, Fax: +81 358006530, e-mail: yamayasu-tky@umin.ac.jp Key Words: Antimicrobial peptide, cytotoxicity, membrane damage.
}

leukocytes and various types of epithelial cells constitutively, or in response to microbial signals and inflammatory cytokines (4-6).

Human $\beta$-defensin-3 (hBD3) was first isolated from human skin (7) and its expression was detected in many tissues, including airway epithelial cells $(8,9)$. In contrast to other defensin isoforms, the prominent features of hBD3 antimicrobial activity are its salt-independency and its broad antimicrobial spectrum $(7,10,11)$.

While antimicrobial peptides have attracted attention as potential molecules to treat cancer (12), previous observations on the anticancer effects of hBD3 have not been consistent. Some studies hypothesized that hBD3 can be oncogenic because hBD3 is frequently overexpressed in oral squamous cell carcinomas (13-15). Winter et al. indicated that hBD3 inhibited colon cancer-cell migration, although not cell proliferation (16). Moreover, Phan et al. indicated that hBD3 exhibits anticancer effects on various tumor cells through cell permeabilization (17).

Here, we investigated the anticancer activities of various isoforms of $\beta$-defensin on lung cancer cells, and confirmed that this anticancer activity is also seen in animal models of cancer.

\section{Materials and Methods}

Reagents. Synthetic hBD1, hBD2, hBD3 and human neutrophil peptide-1 (HNP1) peptides were purchased from the PEPTIDE institute (Minoh, Japan), and were dissolved in $0.001 \%$ acetic acid to give a final concentration of $2 \mathrm{mg} / \mathrm{ml}$.

We predicted the mature Defb14 peptide spanning $45 \mathrm{COOH}-$ terminal amino acids as a mouse homolog of $\mathrm{hBD} 3$, identical to the predicted mature peptide of Defb14 from a previous report (18). At the Peptide Institute (Minoh, Japan), we chemically synthesized mature Defb14 peptide $(19,20)$. The synthetic peptide was airoxidized to form three disulfide bonds. The material was eluted as a 
single peak on reverse-phase high-performance liquid chromatography and confirmed by mass spectroscopy. It was lyophilized and dissolved in $0.001 \%$ acetic acid to give a final concentration of $2 \mathrm{mg} / \mathrm{ml}$.

Cell culture. A549 human lung carcinoma cells were obtained from the Cell Resource Center for Biomedical Research, Tohoku University (Sendai-shi, Japan). Lewis lung carcinoma (LLC) cells were obtained from RIKEN BRC (Tsukuba-shi, Japan). The cells were routinely cultured in Dulbecco's modified Eagle's medium, supplemented with $25 \mathrm{U} / \mathrm{ml}$ penicillin, $25 \mu \mathrm{g} / \mathrm{ml}$ streptomycin and $10 \%(\mathrm{v} / \mathrm{v})$ heat-inactivated fetal calf serum (FCS) at $37^{\circ} \mathrm{C}$ in a $5 \%$ $\mathrm{CO}_{2}$-humidified atmosphere. Cell counting was performed using a Coulter Counter (Beckman Coulter, Tokyo, Japan).

Evaluation of propidium iodide (PI) uptake. To evaluate cell membrane damage, we stained the cells cultured in phosphatebuffered saline (PBS) containing $0.9 \mathrm{mM} \mathrm{Ca}^{2+}$ and $0.33 \mathrm{mM} \mathrm{Mg}^{2+}$ or in Dulbecco's modified Eagle's medium containing 10\% (v/v) FCS, using PI and Hoechst 33342. The proportion of damaged cells was determined by dividing the number of PI-positive cells by the number of Hoechst 33342-positive cells in a field of $0.43 \mathrm{~mm}^{2}$ at the center of the culture dishes.

XTT assay. We performed an XTT assay using a Cell Proliferation Kit (Roche Diagnostics, Minato-ku, Tokyo, Japan) to measure the number of viable cells. In accordance with the protocol, $100 \mu \mathrm{l}$ of A549 cell suspension $\left(10^{5}\right.$ cells $\left./ \mathrm{ml}\right)$ was seeded in a $96-$ well plate, and cultured for $48 \mathrm{~h}$ with $20 \mu \mathrm{g} / \mathrm{ml} \mathrm{hBD} 3$ or with $0.001 \%$ acetic acid. The absorbance was measured at $492 \mathrm{~nm}$.

5'-Bromo-2' deoxyuridine (BrdU) assay. We performed a BrdU assay using 5'-Bromo-2' deoxyuridine Labeling \& Detection Kit (Roche Diagnostics). A549 cell suspension $\left(100 \mu \mathrm{l}\right.$ of $10^{5}$ cells $\left./ \mathrm{ml}\right)$ was seeded in a 96-well plate and cultured for $24 \mathrm{~h}$. Subsequently, BrdU was added with $20 \mu \mathrm{g} / \mathrm{ml} \mathrm{hBD} 3$ or with $0.001 \%$ acetic acid, and the cells were incubated for an additional $12 \mathrm{~h}$ before the measurement of BrdU incorporation.

Implantation of cancer cells and subcutaneous infusion of the DefB14 peptide. All the following procedures were approved by the Animal Care and Use Committee of University of Tokyo (P08-095). After anesthetizing 3-month-old C57BL/6J male mice (CLEA Japan, Meguro-ku, Tokyo, Japan) with ketamine and xylazine, we subcutaneously injected $100 \mu \mathrm{l}$ of LLC cell suspension $(1 \times 107$ cells/ml PBS) to form tumors on the back of mice. Eight days after LLC implantation, we selected the mice that had palpable tumors in the back, and grouped them randomly into a Defb14-treated group $(n=8)$ and a vehicle-treated group $(n=8)$. In the Defb14-treated group, an ALZET MINI-Osmotic Pump (model 2002; DURECT, Cupertino, CA, USA) containing $4.17 \mathrm{mg} / \mathrm{ml}$ of Defb14 peptide in PBS was implanted subcutaneously, near the tumor. This pump infused the contained liquid at a rate of $0.5 \mu \mathrm{l} / \mathrm{h}$, which corresponds to $50 \mu \mathrm{g}$ /day of Defb14 peptide. In the vehicle-treated group, an ALZET MINI-Osmotic Pump containing $0.01 \%$ ascetic acid in PBS was implanted subcutaneously, near the tumor. At the start of the infusion, the palpable tumor size was measured. After 9 days of infusion, the weights of the incised tumors was determined.

Statistics. The variables were compared by Student's $t$-test. Statistical significance was defined as a $p$-value of less than 0.05 .

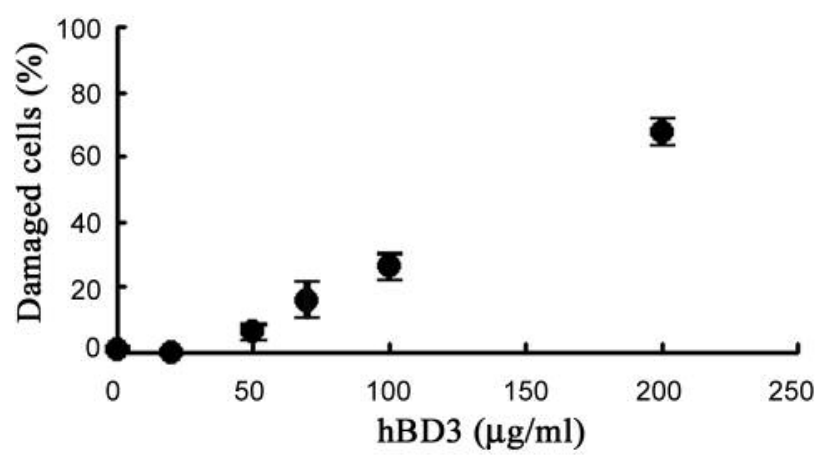

Figure 1. Propidium iodide (PI) uptake after a 10 min treatment with human $\beta$-defensin-3 (hBD3). The percentage of damaged cells was determined by dividing the number of PI-positive cells by the number of all the nuclei after 10 min treatment with hBD3. Data are the mean and the standard error ( $n=9,7,8,4,8$ and 5 at 0, 20, 50, 70, 100 and $200 \mu \mathrm{g} / \mathrm{ml}$ $h B D 3$, respectively). The percentage of damaged cells increased linearly with increasing concentration of $h B D 3$. Treatment with $70 \mu \mathrm{g} / \mathrm{ml}$ or higher concentrations of hBD3 induced a significantly higher proportion of damaged cells compared to no treatment with hBD3 $(p<0.01)$.

\section{Results}

Treatment with hBD3 induced immediate cell membrane damage. A 10-min treatment with hBD3 induced PI uptake in numerous A549 cells, indicating immediate cellmembrane damage. The proportion of damaged cells increased linearly with increasing concentration of hBD3. Treatment with a concentration of hBD3 of $70 \mu \mathrm{g} / \mathrm{ml}$ or higher induced significantly higher proportion of damaged cells $(p<0.01)$ (Figure 1).

The cytotoxic effects of hBD3 were significantly more prominent than HNP-1 $(p<0.01)$. Neither hBD1 nor hBD2 induced PI uptake into A549 cells, even at a concentration of $200 \mu \mathrm{g} / \mathrm{ml}$, for $10 \mathrm{~min}$. Interestingly, Defb14 also showed potent cytotoxicity against A549 cells (Figure 2).

Time-course of cell damage induced by $h B D 3$. Evaluating the time-dependency of the hBD3 cytotoxic effect, we found that the proportion of PI-positive cells increased sharply after 10 min. However, between 10 and $20 \mathrm{~min}$, the increase of PIpositive cells was relatively lower. A slight increase was also seen 40 min after co-incubation with hBD3 (Figure 3A). In prolonged incubation with hBD3 in culture medium containing $10 \%$ (v/v) FCS, hBD3 also induced PI uptake into A549 cells, and the proportion of damaged cells increased almost linearly until 540 min after co-incubation (Figure 3B).

Because of the time-dependent increase in cytotoxicity induced by hBD3, we evaluated the cytotoxic effects of prolonged incubation with the hBD3 peptide at a lower concentration. After a 24-h co-incubation with $20 \mu \mathrm{g} / \mathrm{ml}$ of hBD3 in culture medium containing $10 \%(\mathrm{v} / \mathrm{v}) \mathrm{FCS}, \mathrm{a}$ 


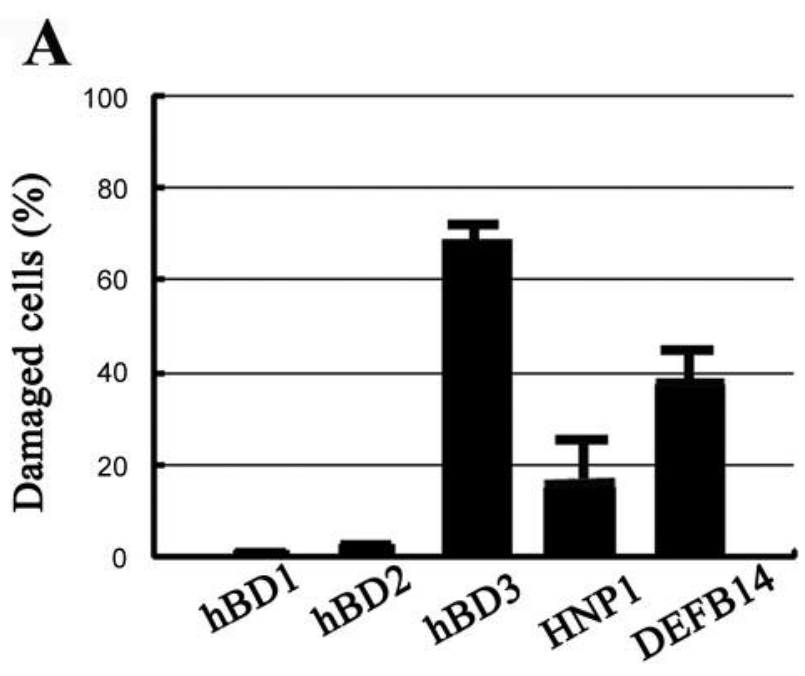

Figure 2. Comparison of cellular damage to A549 cells among defensin family members. A: The percentage of damaged cells was determined by dividing the number of propidium iodide (PI)-positive cells by the number of all nuclei after a 10-min treatment with the indicated defensin isoform at a concentration of $200 \mu \mathrm{g} / \mathrm{ml}$. Data are the mean mean $\pm S E$ ( $n=5$ for $h B D 3, n=3$ for the other defensin members). Treatment for 10 min with $h B D 3$ induced significantly more damaged cells than human $\beta$-defensin-1 ( $h B D 1)(p<0.01)$, human $\beta$-defensin-2 $(h B D 2)(p<0.01)$, and human neutrophil peptide-1 (HNP1) $(p<0.01)$. Defb14, the mouse homolog of $h B D 3$, also induced considerable cellular damage. B: PI staining and respective Hoechst 33342 staining after $10 \mathrm{~min}$ treatment with the indicated defensin isoforms at a concentration of $200 \mu \mathrm{g} / \mathrm{ml}$. Scale bars: $100 \mu \mathrm{m}$.

significantly higher number of A549 cells showed PI uptake than cells incubated without hBD3 (Figure 3C).

As expected, cell counting indicated that the number of A549 cells was significantly lower after a 24-h coincubation with hBD3 peptide at a concentration of 20 $\mu \mathrm{g} / \mathrm{ml}$ (Figure 3D). The XTT assay also confirmed that the number of viable A549 cells was significantly lower after a 48 -h co-incubation with the hBD3 peptide at the same concentration than after a 48-h co-incubation without the hBD-3 peptide (Figure 3E).

In order to examine the effect of hBD3 on cell proliferation, we measured BrdU uptake after a $24-\mathrm{h}$ coincubation with hBD3 peptide at a concentration of $20 \mu \mathrm{g} / \mathrm{ml}$ (Figure 3F). There was no significant difference in BrdU uptake between cells co-incubated with and without hBD3.

Effect of Defbl4 infusion on tumor growth in mice. Subsequently, we evaluated the anticancer activity of Defb14 in vivo. Before beginning the Defb14 peptide infusion, there were no differences in tumor size between the Defb14-treated group and the vehicle-treated group
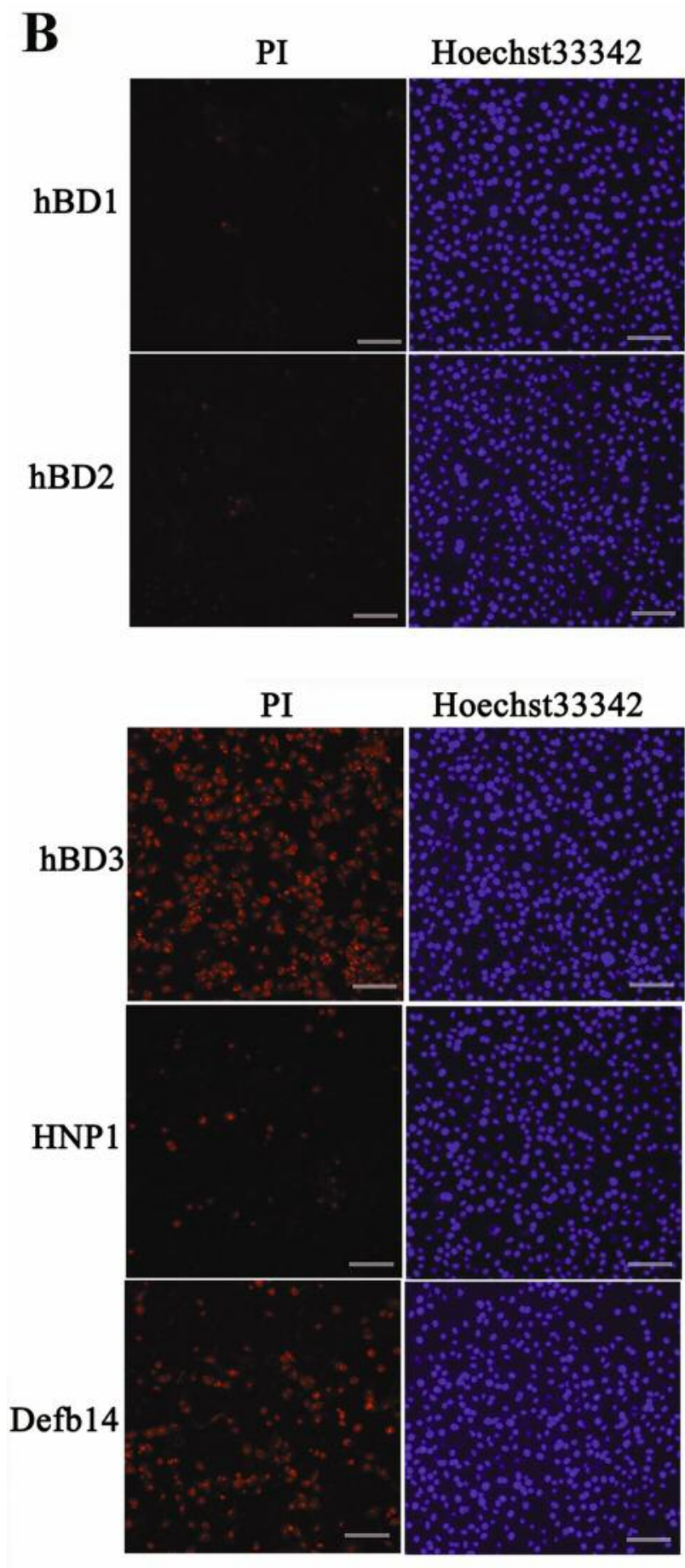

$\left(248.06 \pm 9.80 \mathrm{~mm}^{3}\right.$ and $245.06 \pm 22.66 \mathrm{~mm}^{3}$, respectively, $p=0.45$ ). After a 9-day infusion of Defb14 or vehicle, the tumor weights were significantly lower in the Defb14treated group than in the control group $(p=0.015)$. We observed no apparent damage to normal tissues around the site of Defb14 infusion (Figure 4). 
A

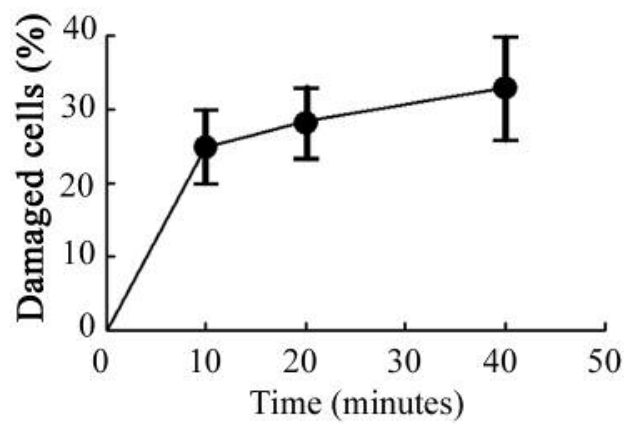

C
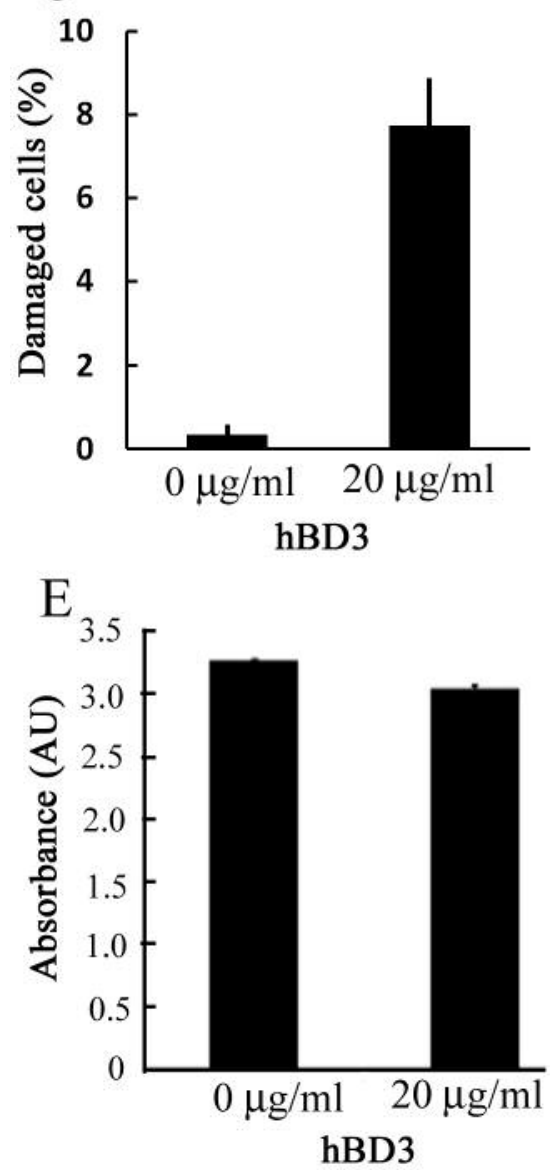

B

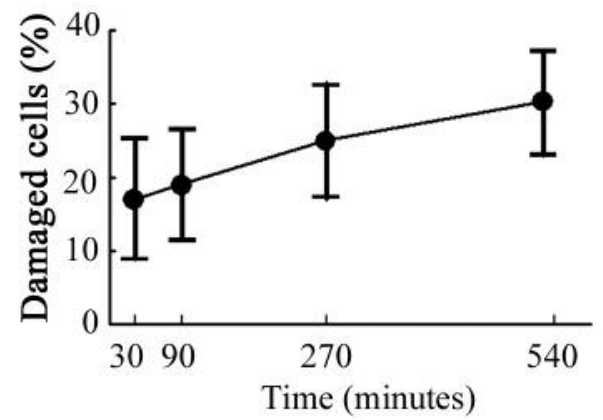

D
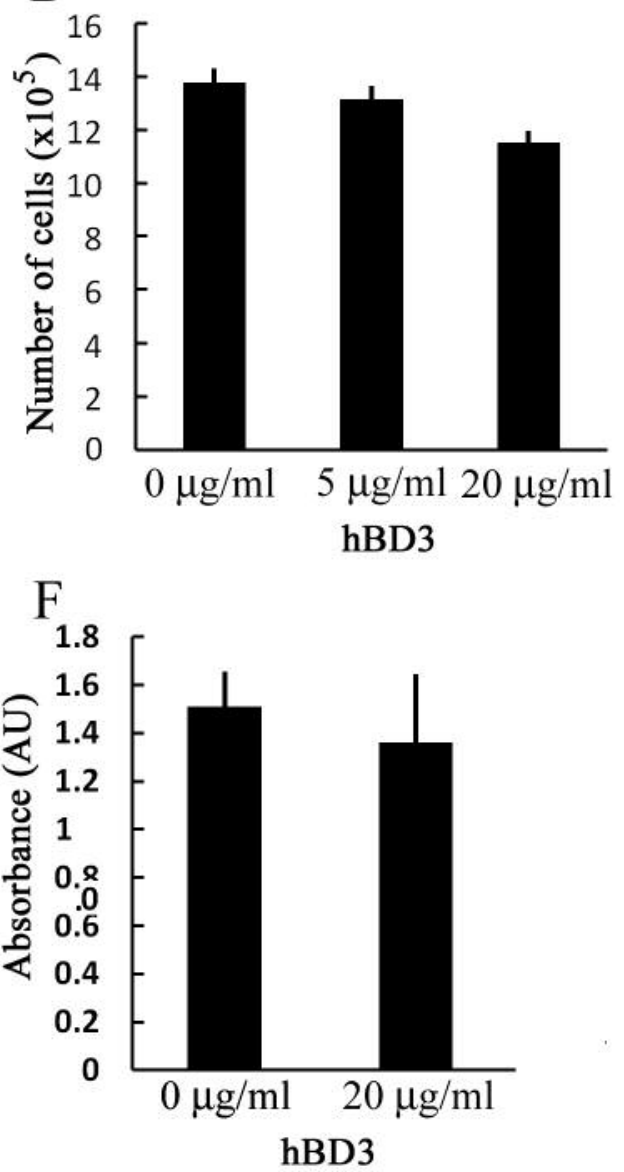

Figure 3. Time dependency of cellular damage induced by human $\beta$-defensin-3 (hBD3). A: Propidium iodide (PI) uptake by A549 cells was observed after 10-, 20- and 40-min incubation with $70 \mu \mathrm{g} / \mathrm{ml}$ of hBD3 in phosphate-buffered saline containing $0.9 \mathrm{mM}$ Ca ${ }^{2+}$ and $0.33 \mathrm{mM} \mathrm{Mg}{ }^{2+}$. The proportion of damaged cells rapidly increased in $10 \mathrm{~min}$. Data are mean $\pm S E$ ( $n=5$ for each incubation time). B: Prolonged incubation with $100 \mu \mathrm{g} / \mathrm{ml}$ of hBD3 in culture medium containing $10 \%(\mathrm{v} / \mathrm{v})$ fetal calf serum (FCS) led to nearly $20 \%$ of the A549 cells taking-up PI after 30 -min incubation and the proportion of damaged cells continued to increase gradually after 90-, 270- and 540-min incubation. Data are the mean \pm SE ( $n=3$ for each incubation time). C: The cytotoxic effects of prolonged incubation with hBD3 peptide were evaluated at a lower concentration. After $24-h$ co-incubation with 20 $\mu \mathrm{g} / \mathrm{ml}$ of hBD3 in culture medium containing $10 \%(\mathrm{v} / \mathrm{v})$ FCS, a significantly higher number of A549 cells showed PI uptake than without hBD-3 $(p<0.01)$. Data are the mean $\pm S E(n=4$ in each group). D: Cell counting indicated that the number of A549 cells was significantly lower after $24-h$ co-incubation with $20 \mu \mathrm{g} / \mathrm{ml}$ hBD3 peptide than without hBD3 ( $<<0.01)$. Data are the mean \pm SE ( $n=4$ in each group). E: The XTT assay showed that the number of A549 cells was significantly lower after 24-h co-incubation with $20 \mu \mathrm{g} / \mathrm{ml}$ hBD3 peptide than without hBD-3 (p<0.01). Data are the mean $\pm S E$ ( $n=5$ in each group). F: There was no significant difference in 5'-bromo-2' deoxyuridine (BrdU) uptake between cells co-incubated with $20 \mu \mathrm{g} / \mathrm{ml} \mathrm{hBD} 3$ peptide for $24 \mathrm{~h}$ and cells incubated without hBD3 peptide. Data are the mean \pm SE ( $n=4$ in each group). 


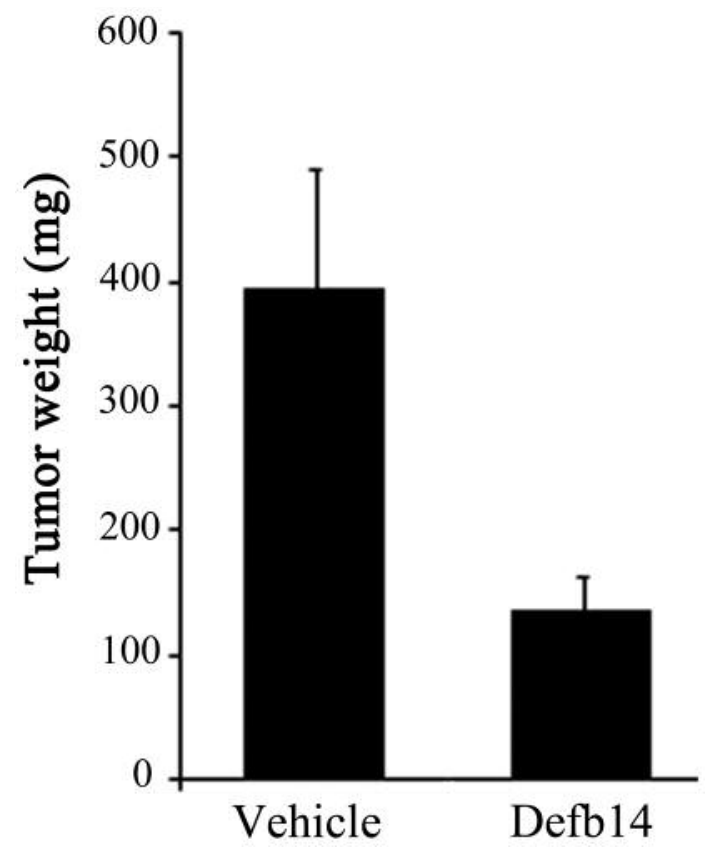

Figure 4. Anticancer activity of Defb14 peptide in mice. Eight days after subcutaneous implantation of Lewis lung carcinoma cells into the back of $C 57 \mathrm{BL} / 6 \mathrm{~J}$ mice, the mice in which the tumors were palpable were grouped randomly into a Defb14-treated group $(n=8)$ and a vehicletreated group $(n=8)$. In the Defb14-treated group, $50 \mu \mathrm{g} /$ day of Defb 14 peptide was subcutaneously infused near the tumor. After 9-day infusion of Defb14 peptide, the excised tumor weights were significantly lower in the Defb14-treated group than in the control group $(p=0.015)$. Data are mean $\pm S E$ ( $n=8$ in each group).

\section{Discussion}

In this study, we investigated the anticancer activities of hBD3 and Defb14. As far as we are aware of, this is the first study to confirm the anticancer activity of defensin in an animal model.

Although many studies have evaluated the association between carcinogenesis and antimicrobial peptides (12), the results have been inconsistent. Some studies indicated that defensin promoted cancer growth $(21,22)$, whereas other studies showed that defensin is cytotoxic $(16,17,23$ 26). Our results suggest that the cytotoxic effect is specific to hBD3 and its mouse homolog, Defb14, among members of the defensin family. Although many studies indicated the cytotoxic effects of HNP1 (23-25), our study showed that the anticancer activity of hBD3 was markedly more potent than that of HNP1. In addition, the presence of serum did not abolish the cellular damage induced by hBD3, whereas a previous report indicated that membrane permeabilization by HNP1 did not occur in the presence of $5 \%$ serum $(25)$
The inconsistency between our findings compared to those from previous investigations reporting that tumors overexpressing hBD3 or Defb14 showed enhanced solidtumor growth remains unclear $(14,15,27)$. This may have occurred because of differences in the concentration of hBD3 and Defb14 used, although the concentration of $20 \mu \mathrm{g} / \mathrm{ml}$ defensin used in our study was not excessively higher than that at which antimicrobial activity was observed (10). Additionally, different pathways may function, if the tumors themselves overexpress defensin $(15,27)$.

Our results for the anticancer activity of hBD3 in lung cancer cells were consistent with those in a recent report by Phan et al. (17). In addition to the in vitro anticancer activity, we first demonstrated the suppression of tumor growth by the Defb14 peptide in mice. Although high concentrations of Defb14 can have harmful effects on normal cells, we observed no damage to normal tissues around the site of Defb14 infusion. Because hBD3 can induce cytokine production, and also be chemotactic for immune cells $(8,18$, 28-31), we were unable to determine whether the suppression of tumor growth in our animal model was because of direct cytotoxic effects of Defb14 or immunoregulatory activities of Defb14. Defb14 may also negatively affect angiogenesis in tumors, although a previous investigation indicated that Defb14 promoted angiogenesis (27). It is difficult to clarify the contribution of immune reactions because cell damage can induce secondary inflammatory responses. Although the precise mechanism remains to be clarified, our observations represent a crucial first step in the application of hBD3 peptide in anticancer therapy.

In conclusion, our study clarified the characteristics of hBD3 anticancer activity on lung cancer cells, and demonstrated for the first time, the suppression of tumor growth by the Defb14 peptide in an animal model.

\section{Acknowledgements}

This work was supported by grants-in-aid from the Ministry of Education, Science, Sports and Culture of Japan (24591154, 15K08899).

\section{References}

1 Hoffmann JA, Kafatos FC, Janeway CA and Ezekowitz RA: Phylogenetic perspectives in innate immunity. Science 284 : 1313-1318, 1999.

2 Schröder JM: Epithelial antimicrobial peptides: innate local host response elements. Cell Mol Life Sci 56: 32-46, 1999.

3 Ganz T and Lehrer RI: Antimicrobial peptides of vertebrates. Curr Opin Immunol 10: 41-44, 1998.

4 Ganz T: Defensins: antimicrobial peptides of innate immunity. Nat Rev Immunol 3: 710-720, 2003.

5 Harder J, Bartels J, Christophers E and Schröder JM: A peptide antibiotic from human skin. Nature 387: 861, 1997. 
6 Yamaguchi Y and Ouchi Y: Antimicrobial peptide defensin: identification of novel isoforms and the characterization of their physiological roles and their significance in the pathogenesis of diseases. Proc Jpn Acad Ser B Phys Biol Sci 88: 152-166, 2012.

7 Harder J, Bartels J, Christophers E and Schröder JM: Isolation and characterization of human beta-defensin-3, a novel human inducible peptide antibiotic. J Biol Chem 276: 5707-5713, 2001.

8 Garcia JR, Jaumann F, Schulz S, Krause A, Rodriguez-Jimenez J, Forssmann U, Adermann K, Kluver E, Vogelmeier C, Becker D, Hedrich R, Forssmann WG and Bals R: Identification of a novel, multifunctional beta-defensin (human beta-defensin 3 ) with specific antimicrobial activity. Its interaction with plasma membranes of Xenopus oocytes and the induction of macrophage chemoattraction. Cell Tissue Res 306: 257-264, 2001.

9 Ishimoto H, Mukae H, Date Y, Shimbara T, Mondal MS, Ashitani J, Hiratsuka T, Kubo S, Kohno S and Nakazato M: Identification of hBD3 in respiratory tract and serum: the increase in pneumonia. Eur Respir J 27: 253-60, 2006.

10 Dhople V, Krukemeyer A and Ramamoorthy A: The human betadefensin-3, an antibacterial peptide with multiple biological functions. Biochim Biophys Acta 1758: 1499-512, 2006.

11 Sudheendra US, Dhople V, Datta A, Kar RK, Shelburne CE, Bhunia A and Ramamoorthy A: Membrane disruptive antimicrobial activities of human $\beta$-defensin-3 analogs. Eur $\mathbf{J}$ Med Chem 91: 91-99, 2015.

12 Papo N and Shai Y: Host defense peptides as new weapons in cancer treatment. Cell Mol Life Sci 62: 784-790, 2005.

13 Kesting MR, Loeffelbein DJ, Hasler RJ, Wolff KD, Rittig A, Schulte M, Hirsch T, Wagenpfeil S, Jacobsen $F$ and Steinstraesser L: Expression profile of human beta-defensin 3 in oral squamous cell carcinoma. Cancer Invest 27: 575-581, 2009.

14 Winter J, Pantelis A, Reich R, Martini M, Kraus D, Jepsen S, Allam JP, Novak N and Wenghoefer M: Human beta-defensin$1,-2$ and -3 exhibit opposite effects on oral squamous cell carcinoma cell proliferation. Cancer Invest 29: 196-201, 2011.

15 Shuyi Y, Feng W, Jing T, Hongzhang H, Haiyan W, Pingping M, Liwu Z, Zwahlen RA and Hongyu Y: Human beta-defensin-3 (hBD3) upregulated by LPS via epidermal growth factor receptor (EGFR) signaling pathways to enhance lymphatic invasion of oral squamous cell carcinoma. Oral Surg Oral Med Oral Pathol Oral Radiol Endod 112: 616-625, 2011.

16 Uraki S, Sugimoto K, Shiraki K, Tameda M, Inagaki Y, Ogura S, Kasai C, Nojiri K, Yoneda M, Yamamoto N, Takei Y, Nobori $\mathrm{T}$ and Ito $\mathrm{M}$ : Human $\beta$-defensin-3 inhibits migration of colon cancer cells via down-regulation of metastasis-associated 1 family, member 2 expression. Int J Oncol 45: 1059-1064, 2014.

17 Phan TK, Lay FT, Poon IK, Hinds MG, Kvansakul M and Hulett MD: Human $\beta$-defensin 3 contains an oncolytic motif that binds $\mathrm{PI}(4,5) \mathrm{P} 2$ to mediate tumour cell permeabilisation. Oncotarget 7: 2054-2069, 2016.

18 Röhrl J, Yang D, Oppenheim JJ and Hehlgans T: Identification and Biological Characterization of Mouse beta-defensin 14, the orthologue of human beta-defensin 3. J Biol Chem 283: 54145419, 2008.

19 Yamaguchi Y, Fukuhara S, Nagase T, Tomita T, Hitomi S, Kimura S, Kurihara $\mathrm{H}$ and Ouchi Y: A novel mouse betadefensin, mBD6, predominantly expressed in skeletal muscle. J Biol Chem 276: 31510-31514, 2001.
20 Yamaguchi Y, Nagase T, Makita R, Fukuhara S, Tomita T, Tominaga T, Kurihara $\mathrm{H}$ and Ouchi $\mathrm{Y}$ : Identification of multiple novel epididymis-specific beta-defensin isoforms in humans and mice. J Immunol 169: 2516-2523, 2002.

21 Aarbiou J, Ertmann M, van Wetering S, van Noort P, Rook D, Rabe KF, Litvinov SV, van Krieken JH, de Boer WI and Hiemstra PS: Human neutrophil defensins induce lung epithelial cell proliferation in vitro. J Leukoc Biol 72: 167-174, 2002.

22 Shi N, Jin F, Zhang X, Clinton SK, Pan Z and Chen T: Overexpression of human $\beta$-defensin 2 promotes growth and invasion during esophageal carcinogenesis. Oncotarget 5: 1133311344, 2014.

23 Lichtenstein A: Mechanism of mammalian cell lysis mediated by peptide defensins. Evidence for an initial alteration of the plasma membrane. J Clin Invest 88: 93-100, 1991.

24 Leelakanok N, Fischer CL, Bates AM, Guthmiller JM, Johnson GK, Salem AK, Brogden KA and Brogden NK: Cytotoxicity of HBD3 for dendritic cells, normal human epidermal keratinocytes, hTERT keratinocytes and primary oral gingival epithelial keratinocytes in cell culture conditions. Toxicol Lett 239: 90-96, 2015.

25 Lichtenstein A, Ganz T, Selsted ME and Lehrer RI: In vitro tumor cell cytolysis mediated by peptide defensins of human and rabbit granulocytes. Blood 68: 1407-1410, 1986.

26 Yamaguchi Y, Nagase T, Tomita T, Nakamura K, Fukuhara S, Amano T, Yamamoto H, Ide Y, Suzuki M, Teramoto S, Asano T, Kangawa K, Nakagata N, Ouchi Y and Kurihara H: Beta-defensin overexpression induces progressive muscle degeneration in mice. Am J Physiol Cell Physiol 292: C2141-C2149, 2007.

27 Röhrl J, Huber B, Koehl GE, Geissler EK and Hehlgans T: Mouse $\beta$-defensin 14 (Defb14) promotes tumor growth by inducing angiogenesis in a CCR6-dependent manner. J Immunol 188: 4931-4939, 2012.

28 Sakamoto N, Mukae H, Fujii T, Ishii H, Yoshioka S, Kakugawa T, Sugiyama K, Mizuta Y, Kadota J, Nakazato M and Kohno S: Differential effects of alpha- and beta-defensin on cytokine production by cultured human bronchial epithelial cells. Am J Physiol Lung Cell Mol Physiol 288: L508-L513, 2005.

29 Niyonsaba F, Ushio H, Nagaoka I, Okumura K and Ogawa H: The human beta-defensins (-1, -2, -3, -4) and cathelicidin LL-37 induce IL-18 secretion through p38 and ERK MAPK activation in primary human keratinocytes. J Immunol 175: 1776-1784, 2005.

30 Röhrl J, Yang D, Oppenheim JJ and Hehlgans T: Human betadefensin 2 and 3 and their mouse orthologs induce chemotaxis through interaction with CCR2. J Immunol 184: 6688-6694, 2010.

31 Funderburg N, Lederman MM, Feng Z, Drage MG, Jadlowsky J, Harding CV, Weinberg A and Sieg SF: Human $\beta$-defensin-3 activates professional antigen-presenting cells via Toll-like receptors 1 and 2. Proc Natl Acad Sci USA 104: 18631-18635, 2007.

Received July 23, 2016

Revised August 15, 2016 Accepted August 18, 2016 